\title{
KEANEKARAGAMAN PERTUMBUHAN DAN HASIL TANAMAN OYONG (LUFFA ACUTANGULA L.) PADA BERBAGAI KONSENTRASI KOLKHISIN
}

\author{
Adib Fauzan Rahman ${ }^{1)}$, Nandariyah ${ }^{2)}$, Parjanto ${ }^{2)}$ \\ 1) Mahasiswa Program Studi Agroteknologi Fakultas Pertanian Universitas Sebelas Maret Surakarta \\ 2) Dosen Program Studi Agroteknologi Fakultas Pertanian Universitas Sebelas Maret Surakarta \\ Contact Author: adib_fauzan@yahoo.com
}

\begin{abstract}
Oyong production is still low due to the limited availability of quality seeds. The production can be increased by one of the plant breeding techniques, which is mutation technique. The technique of mutation by chemical mutagens is able to increase the genetic diversity ofplants allowing the breeding to select genotype of plants in accordance with the intended breeding objective. Therefore, research is required to be conducted by using colchicin as a chemical mutagen which causes polyploid, in which organism has three sets or more chromosomes inside its cells. Meanwhile, the general nature of this polyploid plant is being sturdier; parts of the plantare bigger; so that later, its poor nature will be better as well as changing the potency of the result. Research using complete randomized block design (RBD) with one factor concentration of $0,1 \%(P 1), 0,2 \%(P 2), 0,3 \%(P 3), 0,4 \%(P 4), 0,5 \%$ ( P5), and $0,6 \%$ (P6). Colchicines treatment can cause changes in growth and yield variables. Colchicines treatment with a concentration of $0,3 \%$ showed positive changes to theweight of fruit, fruit diameter and length of the fruit. An increase in diversity on growth and yield components especially on colchicines treatment with $0,3 \%$ concentration.
\end{abstract}

Keywords: Ridged gourd, Mutation, Polyploid, Colchicines

\section{AGROTECHNOLOGY RESEARCH JOURNAL}

Rahman AD, Nandariyah, Parjanto. 2017. Keanekaragaman pertumbuhan dan hasil tanaman oyong (Luffa acutangula L.) pada berbagai konsentrasi kolkhisin. Agrotech Res J 1(1):1-6.

Rahman AD, Nandariyah,Parjanto (2017). The diversity in growth and yield of ridged gourd (Luffa acutangula L.) on various colchicin concentration. Agrotech Res J 1(1):1-6.

\section{PENDAHULUAN}

Oyong (Luffa acutangula L.) atau ridged gourd, disebut juga gambas. Tanaman ini termasuk dalam famili Cucurbitaceae, berasal dari India, namun telah beradaptasi baik di Asia Tenggara termasuk Indonesia.Belum banyak petani yang menanam oyong di daerah Yogyakarta sehingga oyong memiliki harga yang cukup tinggi.Data potensi tanaman oyong di Provinsi Yogyakarta hingga saat ini masih belum ada dikarenakan produksi yang masih rendah serta ketersediaan bibit unggul yang masih terbatas.

Produksi dapat ditingkatkan salah satunya dengan teknik pemuliaan tanaman.Dalam bidang pemuliaan tanaman, teknik mutasi dapat meningkatkan keragaman genetik tanaman memungkinkan pemuliaan melakukan seleksi genotipe tanaman sesuai dengan tujuan pemuliaan yang dikehendaki.Mutasi dapat dilakukan pada tanaman dengan perlakuan bahan mutagen tertentu terhadap organ tanaman seperti biji, stek batang, serbuk sari, akar, rizoma. Media ukur jaringan dan sebagainya Salah satu mutagen kimia adalah kolkhisin. Kolkhisin merupakan salah satu reagen untuk mutasi yang menyebabkan terjadinya poliploid dimana organisme memiliki tiga set atau lebih kromosom dalam selselnya, sedangkan sifat umum dari tanaman poliploid ini adalah menjadi lebih kekar, bagian tanaman lebih besar (akar, batang, daun, bunga, dan buah), sehingga nantinya sifat-sifat yang kurang baik akan menjadi lebih baik sehingga mengubah potensi hasilnya (Sulistianingsih 2006).

*Fak. Pertanian UNS Surakarta

Jl. Ir. Sutami 36 A Surakarta

\section{METODE PENELITIAN}

Penelitian ini dilaksanakan kurang lebih selama 4 bulan pada bulan Februari 2016 sampai bulan Mei 2016 bertempat di desa Onggobayan, Kasihan, Bantul. Bahan yang digunakan dalam penelitian ini adalah benih oyong varietas Prima, Kolkhisin, Pupuk NPK (16:16:16), Urea dan Pupuk Kandang. Alat yang digunakan dalam penelitian ini adalah cangkul, sabit, tali, papan nama, meteran, ajir, timbangan analitik, Jangka sorong dan kamera.

Rancangan percobaan yang digunakan adalah Rancangan Acak Kelompok Lengkap (RAKL) dengan 1 faktor yaitu konsentrasi. Terdiri dari Tanpa Kolkhisin Tanpa Perendaman (P0) sebagai kontrol, Konsentrasi Kolkisin 0,1 \% (P1), Konsentrasi Kolkisin 0,2 \% (P2), Konsentrasi Kolkisin 0,3 \% (P3), Konsentrasi Kolkisin $0,4 \%$ (P4), Konsentrasi Kolkisin 0,5\% (P5), Konsentrasi Kolkisin 0,6 \% (P6) Perlakuan diulang sebanyak 3 kali sehingga terdapat 21 petak percobaan. Data dianalisis secara deskriptif setiap individu dan dilakukan pembandingan tanaman perlakuan dengan tanaman kontrol serta dianalisis dengan analisis keragaman atau Analysis of Varian (Anova), dan jika terdapat perbedaan yang nyata dilanjutkan dengan uji jarak berganda Duncan's (DMRT) pada taraf kepercayaan $5 \%$.

\section{HASIL DAN PEMBAHASAN}

\section{Presentase benih tumbuh}

Gambar 1 menunjukkan bahwa persentase hidup terendah adalah P6 yaitu konsentrasi kolkisin 0,6 \%. 
Perlakuan konsentrasi kolkisin yang tidak tepat dapat mengakibatkan banyak tanaman yang mati. Hal ini sesuai dengan pernyataan Suryo (2007) yang menyatakan bahwa kolkisin bersifat racun terutama pada tumbuhan memperlihatkan pengaruhnya pada nukleus yang sedang membelah. Sehingga akan mempengaruhi pertumbuhan dan perkembangan tanaman tersebut. Jika konsentrasi larutan kolkhisin kurang mencapai keadaan yang tepat, maka poliploidi belum dapat diperoleh. Sebaliknya jika konsentrasinya terlalu tinggi, maka kolkhisin memperlihatkan pengaruh negatif, yaitu penampilan tanaman menjadi lebih jelek, sel-sel banyak yang rusak atau bahkan menyebabkan tanaman mati.

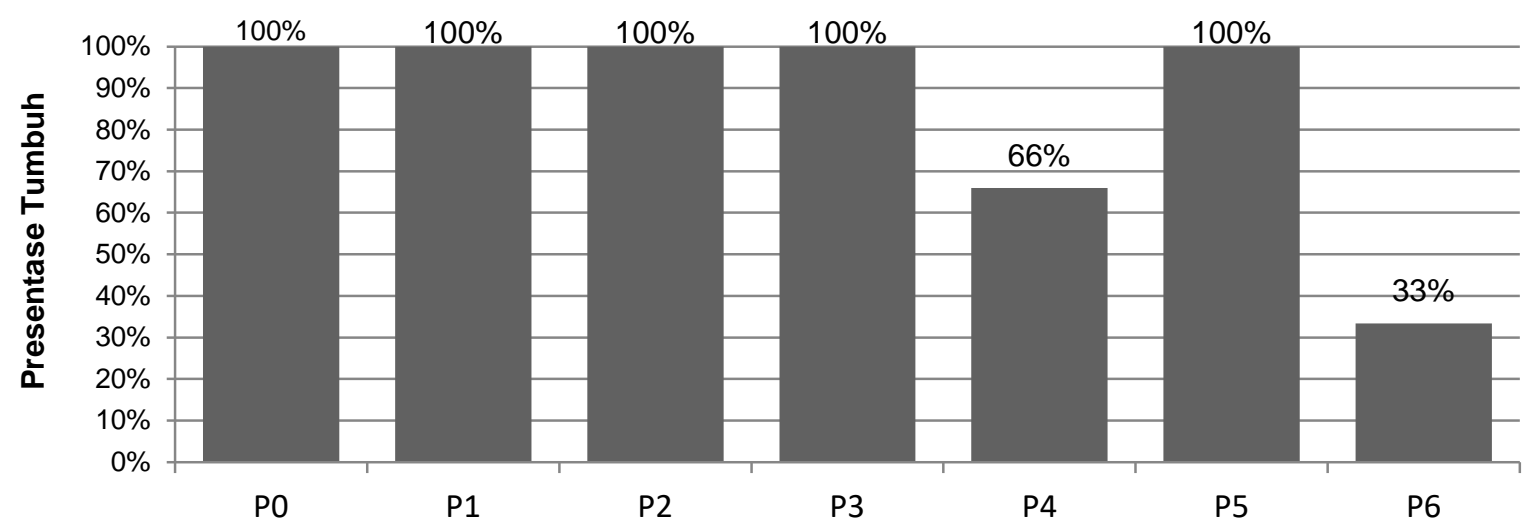

Keterangan:

P0: Kontrol

P1: Konsentrasi Kolkhisin 0,1\%

P2: Konsentrasi Kolkhisin 0,2 \%

P3: Konsentrasi Kolkhisin 0,3\%

P4: Konsentrasi Kolkhisin 0,4 \%

P5: Konsentrasi Kolkhisin 0,5\%

P6: Konsentrasi Kolkhisin 0,6 \%

Gambar 1 Diagram batang persentase benih tumbuh pada berbagai konsentrasi kolkhisin

\section{Tinggi tanaman}

Tabel 1 menunjukkan bahwa tinggi tanaman 14 HST tertinggi adalah P0 yaitu tanpa kolkisin. Seluruh perlakuan berbeda nyata terhadap kontrol pada 14 HST. Tinggi tanaman 21 HST adalah P0 yaitu tanpa kolkisin. Seluruh perlakuan berbeda nyata terhadap kontrol pada 21 HST.Tinggi tanaman 28 HST tertinggi adalah P0 yaitu tanpa kolkisin.Seluruh perlakuan juga berbeda nyata terhadap kontrol pada 21 HST. Hasil penelitian ini sejalan dengan Permadi (1991) yang menyatakan bahwa konsentrasi kolkisin menentukan efektivitas induksi poliploidi yang menghasilkan tanaman bawang merah yang lebih pendek.
Tinggi tanaman pada 35 HST pada perlakuan P3, P4 dan P6 berbeda nyata terhadap kontrol. Perlakuan P1, P2 dan P5 tidak berbeda nyata terhadap kontrol. Tabel 2 menunjukkan bahwa tinggi tanaman 35 hari setelah tanam tertinggi adalah $\mathrm{P} 1$ yaitu kolkisin $0,1 \%$. Tinggi tanaman menjadi tidak berbeda nyata setelah 35 HST.Hal ini menunjukkan bahwa terjadi hambatan pertumbuhan tinggi tanaman akibat perlakuan kolkisin hanya pada awal pertumbuhan sedang pada pertumbuhan selanjutnya tidak ada hambatan berpengaruh. Menurut Suryo (2007) perlakuan kolkisin mengakibatkan penghambatan fisiologi pada tanaman sehingga menunjukkan penampilan tinggi tanaman terhambat.

Tabel 1 Pengaruh konsentrasi kolkisin terhadap tinggi tanaman

\begin{tabular}{|c|c|c|c|c|}
\hline \multirow[t]{2}{*}{ Perlakuan } & \multicolumn{4}{|c|}{ Pengaruh konsentrasi kolkisin terhadap tinggi tanaman $(\mathrm{cm})$} \\
\hline & $14 \mathrm{HST}$ & $21 \mathrm{HST}$ & 28 HST & 35 HST \\
\hline $\mathrm{PO}$ & $292,25 a$ & $302,67 c$ & $432,58 d$ & $433,17 d$ \\
\hline P1 & $158,67 \mathrm{c}$ & $220,33 a b$ & $334,17 \mathrm{bc}$ & $439,33 d$ \\
\hline $\mathrm{P} 2$ & $149,50 \mathrm{ac}$ & $224,92 a b$ & $343,58 b c$ & $399,25 b c d$ \\
\hline P3 & $118,08 a b c$ & $221,75 a, b$ & $319,33 b c$ & $360,33 b c$ \\
\hline P4 & $73,00 \mathrm{a}$ & $182,79 a$ & $305,46 a b$ & $352,00 b$ \\
\hline P5 & $148,92 \mathrm{ac}$ & $245,33 b$ & $364,08 c$ & $405,75 \mathrm{~cd}$ \\
\hline P6 & $85,83 a b$ & $177,83 a$ & $264,17 a$ & $264,17 a$ \\
\hline
\end{tabular}

Keterangan : Nilai yang diikuti huruf yang berbeda menunjukkan berbeda nyata pada DMRT taraf $5 \%$, P1: Konsentrasi Kolkhisin 0,1 \%, P2: Konsentrasi Kolkhisin 0,2 \%, P3: Konsentrasi Kolkhisin 0,3 \%, P4: Konsentrasi Kolkhisin 0,4 \%, P5: Konsentrasi Kolkhisin 0,5 \%, P6: Konsentrasi Kolkhisin 0,6 \%. 


\section{Diameter batang}

Perlakuan P3, P4, P5 dan P6 berbeda nyata terhadap kontrol pada 35 HST.Perlakuan P1 dan P2 tidak berbeda nyata terhadap kontrol. Tabel 2 menunjukkan bahwa diameter batang $35 \mathrm{HST}$ terbesar adalah P0 yaitu tanpa kolkisin. Konsentrasi kolkisin yang tinggi justru menghambat pertumbuhan tanaman 35 HST. konsentrasi kolkisin 0,6\% justru menghambat pertumbuhan diameter batang. Hal ini tidak sejalan dengan Sarathum et al. (2010) yang menyatakan bahwa poliploidi juga dapat menghasilkan tanaman dengan batang dan akar yang lebih besar.Diduga tanaman mengalami perlambatan pertumbuhan akibat perlakuan kolkhisin sehingga pertumbuhan batang lebih lambat sehingga perlu diamati diameter batang pada saat panen terakhir.

Tabel 2 Pengaruh konsentrasi kolkisin terhadap diameter batang

\begin{tabular}{lrrrr} 
Perlakuan & \multicolumn{4}{c}{ Pengaruh konsentrasi kolkisin terhadap diameter batang (mm) } \\
\cline { 2 - 5 } & $14 \mathrm{HST}$ & $21 \mathrm{HST}$ & $28 \mathrm{HST}$ & $35 \mathrm{HST}$ \\
\hline P0 & $7,69 \mathrm{c}$ & $7,99 \mathrm{~b}$ & $8,18 \mathrm{c}$ & $8,18 \mathrm{~b}$ \\
P1 & $6,64 \mathrm{ab}$ & $7,83 \mathrm{~b}$ & $8,03 \mathrm{bc}$ & $8,10 \mathrm{~b}$ \\
P2 & $6,53 \mathrm{ab}$ & $7,27 \mathrm{ab}$ & $7,51 \mathrm{abc}$ & $7,53 \mathrm{ab}$ \\
P3 & $6,15 \mathrm{bc}$ & $7,15 \mathrm{a}$ & $7,15 \mathrm{a}$ & $7,16 \mathrm{a}$ \\
P4 & $6,21 \mathrm{a}$ & $7,00 \mathrm{a}$ & $7,06 \mathrm{a}$ & $7,07 \mathrm{a}$ \\
P5 & $6,62 \mathrm{ab}$ & $7,30 \mathrm{ab}$ & $7,36 \mathrm{ab}$ & $7,15 \mathrm{a}$ \\
P6 & $6,40 \mathrm{ab}$ & $6,85 \mathrm{a}$ & $7,02 \mathrm{a}$ & $7,02 \mathrm{a}$ \\
\hline
\end{tabular}

Keterangan : Nilai yang diikuti huruf yang berbeda menunjukkan berbeda nyata pada DMRT taraf $5 \%, \mathrm{P} 1$ : Konsentrasi Kolkhisin 0,1\%, P2: Konsentrasi Kolkhisin 0,2 \%, P3: Konsentrasi Kolkhisin 0,3 \%, P4: Konsentrasi Kolkhisin 0,4 \%, P5: Konsentrasi Kolkhisin 0,5\%, P6: Konsentrasi Kolkhisin 0,6 \%.

\section{Luas daun}

Tabel 3 menunjukkan bahwa rerata luas daun tertinggi adalah P6 yaitu konsentrasi kolkisin $0,6 \%$. Perlakuan seluruhnya berbeda nyata terhadap kontrol. Luas daun terkecil pada perlakuan P2 yaitu $184,61 \mathrm{~cm}^{2}$ sedangkan luas daun terbesar pada perlakuan P6 yaitu $605,87 \mathrm{~cm}^{2}$. Keanekaragaman tertinggi pada perlakuan P6 yang dengan kisaran luas daun 262,05$605,87 \mathrm{~cm}^{2}$. Hasil ini menunjukkan perlakuan kolkisin memperbesar pertumbuhan luas daun. Hal serupa juga diperoleh oleh Rahayu (1999) dalam penelitiannya terhadap kacang tanah. Hasil perlakuan kolkisin memberikan perbedaan dibandingkan kontrol yaitu ukuran daun yang menjadi lebih pendek dan lebih lebar, bentuk helaian daun tanaman dengan kolkisin menjadi lebih bulat. Haryati et al. (2009) menambahkan bahwa pada tanaman poliploid, jumlah kromosom yang lebih banyak menyebabkan ukuran sel dan inti sel yang lebih besar. Sel yang berukuran lebih besar menghasilkan bagian tanaman seperti daun, bunga, buah maupun tanaman secara kesekuruhan yang lebih besar.

Tabel 3 Pengaruh konsentrasi kolkisin terhadap luas daun

\begin{tabular}{lrrrr}
\hline Perlakuan & Terkecil & Terbesar & Kisaran & Rata-rata $\left(\mathrm{cm}^{2}\right)$ \\
\hline P0 & & & $229,16 \mathrm{a}$ \\
P1 & 213,73 & 245,94 & $213,73-245,94$ & $353,37 \mathrm{~b}$ \\
P2 & 245,32 & 547,64 & $245,32-547,64$ & $310,73 \mathrm{~b}$ \\
P3 & 184,61 & 464,01 & $184,61-464,01$ & $325,34 \mathrm{~b}$ \\
P4 & 221,16 & 452,24 & $221,16-452,24$ & $301,31 \mathrm{~b}$ \\
P5 & 201,34 & 363,03 & $201,34-363,03$ & $309,18 \mathrm{~b}$ \\
P6 & 221,16 & 455,33 & $221,16-455,33$ & $478,36 \mathrm{c}$ \\
\hline
\end{tabular}

Keterangan : Nilai yang diikuti huruf yang berbeda menunjukkan berbeda nyata pada DMRT taraf $5 \%, \mathrm{P} 1$ : Konsentrasi Kolkhisin 0,1\%, P2: Konsentrasi Kolkhisin 0,2 \%, P3: Konsentrasi Kolkhisin 0,3 \%, P4: Konsentrasi Kolkhisin 0,4 \%, P5: Konsentrasi Kolkhisin 0,5 \%, P6: Konsentrasi Kolkhisin 0,6 \%.

\section{Umur berbunga}

Tabel 4 menunjukkan bahwa rerata umur bunga terpendek adalah P0 yaitu tanpa kolkisin. Umur bunga terpendek pada perlakuan P0 yaitu 12 HSTsedangkan umur berbunga terbesar pada perlakuan P5 yaitu 16 HST.Perlakuan seluruhnya berbeda nyata terhadap kontrol.Keanekaragaman tertinggi pada perlakuan P5 yang dengan kisaran umur panen 14-20 HST. Perlakuan kolkisin akan menambah umur berbunga.
Poehlman dan Sleper (1995) menyatakan bahwa ukuran sel tanaman poliploid seringkali membesar namun jumlahnya berkurang. Membesarnya ukuran sel mengakibatkan efisiensi metabolisme tanaman menurun sehingga pertumbuhannya terhambat dan waktu berbunganya melambat. Hal ini juga sesuai dengan penelitian Sofia (2007) dimana konsentrasi kolkhisin pada timun dapat memperlambat umur berbunga. 
Tabel 4 Pengaruh konsentrasi kolkisin terhadap umur berbunga

\begin{tabular}{lrrrr}
\hline Perlakuan & Terkecil & Terbesar & Kisaran & Rata-rata (HST) \\
\hline P0 & 12 & 13 & $12-13$ & $12 \mathrm{a}$ \\
P1 & 15 & 20 & $15-20$ & $17 \mathrm{~b}$ \\
P2 & 14 & 17 & $14-17$ & $16 \mathrm{~b}$ \\
P3 & 14 & 17 & $14-17$ & $17 \mathrm{~b}$ \\
P4 & 16 & $16-17$ & $16 \mathrm{~b}$ \\
P5 & 14 & $14-20$ & $16 \mathrm{~b}$ \\
P6 & 16 & 18 & $16-18$ & . \\
\hline
\end{tabular}

Keterangan : Nilai yang diikuti huruf yang berbeda menunjukkan berbeda nyata pada DMRT taraf $5 \%, \mathrm{P} 1$ : Konsentrasi Kolkhisin 0,1\%, P2: Konsentrasi Kolkhisin 0,2 \%, P3: Konsentrasi Kolkhisin 0,3 \%, P4: Konsentrasi Kolkhisin 0,4 \%, P5: Konsentrasi Kolkhisin 0,5 \%, P6: Konsentrasi Kolkhisin 0,6 \%.

\section{Umur panen}

Tabel 5 menunjukkan bahwa rerata umur panen terpendek adalah PO yaitu tanpa kolkisin. Umur panen terpendek pada perlakuan P0 yaitu 48 HST sedangkan umur panen terbesar pada perlakuan P1 dan P3 yaitu 57 HST.Keanekaragaman tertinggi pada perlakuan P1 dan P3 yang dengan kisaran umur panen 52-57 HST. Perlakuan kolkisin akan memperpanjang umur panen. Herawati dan Ridwan (2000) menyatakan bahwa salah satu ciri poliploid yaitu kecepatan pertumbuhan lebih lambat dibanding diploid, menyebabkan pembungaanya juga terlambat. Sehingga menyebabkan umur panen juga terlambat. Hasil penelitian Rahayu (1999) juga menunjukkan bahwa konsentrasi kolkhisin $10 \mathrm{ppm}$ dengan lama perendaman $10,15,30$, dan 45 menit telah dapat mempengaruhi umur panen menjadi lebih lama, bobot biji / plot, bobot 100 biji, dan jumlah kromosom tanaman kacang tanah.

Tabel 5 Pengaruh konsentrasi kolkisin terhadap umur panen

\begin{tabular}{lrrrr}
\hline Perlakuan & Terkecil & Terbesar & Kisaran & Rata-rata (HST) \\
\hline P0 & 48 & 49 & $48-49$ & $48 \mathrm{a}$ \\
P1 & 52 & 57 & $52-57$ & $54 \mathrm{c}$ \\
P2 & 52 & 53 & $52-53$ & $53 \mathrm{~b}$ \\
P3 & 52 & 57 & $52-57$ & $53 \mathrm{~b}$ \\
P4 & 52 & 54 & $52-54$ & $53 \mathrm{~b}$ \\
P5 & 52 & 54 & $52-54$ & $56 \mathrm{~d}$ \\
P6 & 56 & 56 & $56-56$ & \\
\hline
\end{tabular}

Keterangan : Nilai yang diikuti huruf yang berbeda menunjukkan berbeda nyata pada DMRT taraf $5 \%, \mathrm{P} 1$ : Konsentrasi Kolkhisin 0,1\%, P2: Konsentrasi Kolkhisin 0,2 \%, P3: Konsentrasi Kolkhisin 0,3 \%, P4: Konsentrasi Kolkhisin 0,4 \%, P5: Konsentrasi Kolkhisin 0,5\%, P6: Konsentrasi Kolkhisin 0,6 \%.

\section{Jumlah buah pertanaman}

Tabel 6 menunjukan bahwa perlakuan P1, P2, P3 dan P4 tidak berbeda nyata terhadap kontrol sedangkan perlakuan P5 dan P6 berbeda nyata terhadap kontrol. Tabel 6 menunjukan bahwa rerata jumlah buah pertanam terbanyak adalah P5 yaitu konsentrasi kolkisin 0,5\%. jumlah buah pertanaman terkecil pada perlakuan P0 yaitu 7 buah sedangkan jumlah buah pertanaman terbesar pada perlakuan P0 dan P5 yaitu 13 buah. Keanekaragaman tertinggi pada perlakuan P0 dengan kisaran jumlah buah pertanaman 7-13 buah. Diduga konsentrasi kolkhisin yang tepat akan menghasilkan tanaman dengan jumlah buah pertanam yang lebih banyak.

Tabel 6 Pengaruh konsentrasi kolkisin terhadap jumlah buah pertanaman

\begin{tabular}{lrrrr}
\hline Perlakuan & Terkecil & Terbesar & Kisaran & Rata-rata (buah) \\
\hline P0 & 7 & 13 & $7-13$ & $10 \mathrm{bc}$ \\
P1 & 10 & 12 & $10-12$ & $10 \mathrm{~cd}$ \\
P2 & 10 & 12 & $10-12$ & $10 \mathrm{~cd}$ \\
P3 & 10 & 12 & $10-12$ & $11 \mathrm{~cd}$ \\
P4 & 8 & 10 & $8-10$ & $9 \mathrm{ab}$ \\
P5 & 10 & 13 & $10-13$ & $11 \mathrm{~d}$ \\
P6 & 8 & 10 & $8-10$ & $9 \mathrm{a}$ \\
\hline
\end{tabular}

Keterangan : Nilai yang diikuti huruf yang berbeda menunjukkan berbeda nyata pada DMRT taraf $5 \%, \mathrm{P} 1$ : Konsentrasi Kolkhisin 0,1\%, P2: Konsentrasi Kolkhisin 0,2 \%, P3: Konsentrasi Kolkhisin 0,3 \%, P4: Konsentrasi Kolkhisin 0,4 \%, P5: Konsentrasi Kolkhisin 0,5\%, P6: Konsentrasi Kolkhisin 0,6 \%.

\section{Bobot basah buah}

Tabel 7 menunjukan bahwa perlakuan P1, P2, dan P3 berbeda nyata terhadap kontrol. Perlakuan P4, P5 dan P6 tidak berbeda nyata terhadap kontrol. Tabel 7 menunjukkan bahwa rerata bobot buah basah terbesar adalah P3 yaitu konsentrasi kolkisin $0,3 \%$. Bobot basah buah terkecil pada perlakuan P5 yaitu 240 gram 
sedangkan bobot basah buah terbesar pada perlakuan P3 yaitu 708,3 gram. Keanekaragaman tertinggi pada perlakuan P3 yang dengan kisaran bobot basah buah 271-708,3 gram. Diduga perlakuan konsentrasi kolkisin yang sesuai akan menghasilkan bobot buah basah yang lebih besar. Haryanti et al. (2009) menambahkan, pada tanaman poliploid, jumlah kromosom yang lebih banyak menyebabkan ukuran sel dan inti sel yang lebih besar. Sel yang berukuran lebih besar menghasilkan bagian tanaman seperti daun, bunga, buah maupun tanaman secara keseluruhan yang lebih besar.

Tabel 7 Pengaruh konsentrasi kolkisin terhadap bobot buah basah

\begin{tabular}{lrrrr}
\hline Perlakuan & Terkecil & Terbesar & Kisaran & Rata-rata (g) \\
\hline P0 & 300,3 & 364,7 & $300,3-364,7$ & $322,68 \mathrm{a}$ \\
P1 & 334,3 & 680,3 & $334,3-680,3$ & $424,80 \mathrm{~b}$ \\
P2 & 267 & 608,7 & $267-608,7$ & $424,77 \mathrm{~b}$ \\
P3 & 271 & 708,3 & $271-708,3$ & $451,45 \mathrm{~b}$ \\
P4 & 261,3 & 480,7 & $261,3-480,7$ & $367,34 \mathrm{ab}$ \\
P5 & 240 & 538,3 & $240-538,3$ & $383,01 \mathrm{ab}$ \\
P6 & 264,7 & 370 & $264,7-370$ & $315,45 \mathrm{a}$ \\
\hline
\end{tabular}

Keterangan : Nilai yang diikuti huruf yang berbeda menunjukkan berbeda nyata pada DMRT taraf $5 \%$, P1: Konsentrasi Kolkhisin 0,1 \%, P2: Konsentrasi Kolkhisin 0,2 \%, P3: Konsentrasi Kolkhisin 0,3 \%, P4: Konsentrasi Kolkhisin 0,4 \%, P5: Konsentrasi Kolkhisin 0,5 \%, P6: Konsentrasi Kolkhisin 0,6 \%.

\section{Diameter buah}

Tabel 8 menunjukan bahwa perlakuan P2 dan P3 berbeda nyata terhadap kontrol.Perlakuan P1, P4, P5 dan P6 tidak berbeda nyata terhadap kontrol. Gambar 8 menunjukkan bahwa rerata diameter buah basah terbesar adalah P3 yaitu konsentrasi kolkisin 0,3\%. Diameter buah terkecil pada perlakuan P0 yaitu 48,1 $\mathrm{mm}$ sedangkan diameter buah terbesar pada perlakuan P2 yaitu 68,3 mm. Keaneka ragaman tertinggi pada perlakuan P2 yang dengan kisaran panjang buah 48,7-68,3 mm. Perlakuan konsentrasi kolkisin yang sesuai diduga akan menghasilkan diameter buah yang lebih besar. Penelitian yang dilakukan Susianti et al. (2015) juga menampilkan bahwa pemberian kolkisin pada buah stroberi kultivar festival menunjukkan peningkatan diameter buah dengan ukuran sel yang besar. Sheeler dan Bianchi (1983) menyatakan kolkisin sebagai zat mutagenik pada poliploid akan berfungsi menghambat pembentukan mikrotubula, sehingga dinding pemisah tidak terbentuk dan kromosom yang telah mengganda selama profase gagal memisahkan diri. Akibatnya kromosom menjadi berlipat, apabila kromosomnya banyak maka ukuran selnya akan besar, ukuran sel yang besar akan meningkatkan pula ukuran jaringan, sehingga ukuran organnya pun akan mejadi lebih besar

Tabel 8 Pengaruh konsentrasi kolkisin terhadap diameter buah

\begin{tabular}{lrrrr}
\hline Perlakuan & Terkecil & Terbesar & Kisaran & Rata-rata $(\mathrm{mm})$ \\
\hline P0 & 48,1 & 56,8 & $48,1-56,8$ & $53,01 \mathrm{a}$ \\
P1 & 52,3 & 65,9 & $52,3-65,9$ & $58,23 \mathrm{ab}$ \\
P2 & 48,7 & 68,3 & $48,7-68,3$ & $59,65 \mathrm{~b}$ \\
P3 & 52,2 & 65,1 & $52,2-65,1$ & $59,99 \mathrm{~b}$ \\
P4 & 55 & 65,9 & $55-65,9$ & $55,69 \mathrm{ab}$ \\
P5 & 51,6 & 62,1 & $51,6-62,1$ & $56,69 \mathrm{ab}$ \\
P6 & 52 & 56,2 & $52-56,2$ & $53,32 \mathrm{a}$ \\
\hline
\end{tabular}

Keterangan : Nilai yang diikuti huruf yang berbeda menunjukkan berbeda nyata pada DMRT taraf $5 \%$, P1: Konsentrasi Kolkhisin 0,1 \%, P2: Konsentrasi Kolkhisin 0,2 \%, P3: Konsentrasi Kolkhisin 0,3 \%, P4: Konsentrasi Kolkhisin 0,4 \%, P5: Konsentrasi Kolkhisin 0,5 \%, P6: Konsentrasi Kolkhisin 0,6 \%.

\section{Panjang buah}

Tabel 9 menunjukan bahwa semua perlakuan tidak berbeda nyata terhadap kontrol. Tabel 9 menunjukkan bahwa rerata panjang buah basah terbesar adalah P3 yaitu konsentrasi kolkisin 0,3\%. Hal ini berbeda dengan Haryati et al. (2009) bahwa pada tanaman poliploid, jumlah kromosom yang lebih banyak menyebabkan ukuran sel dan inti sel yang lebih besar. Sel yang berukuran lebih besar menghasilkan bagian tanaman seperti daun, bunga, buah maupun tanaman secara kesekuruhan yang lebih besar. Diduga buah tidak bertambah panjang secara signifikan namun bertambah besar diameternya. Panjang buah terkecil pada perlakuan P2 yaitu 28,5 $\mathrm{cm}$ sedangkan panjang buah terbesar pada perlakuan P3 yaitu $47,3 \mathrm{~cm}$ Keaneka ragaman tertinggi pada perlakuan P3 yang dengan kisaran panjang buah 30,9$47,3 \mathrm{~cm}$. 
Tabel 9 Pengaruh konsentrasi kolkisin terhadap panjang buah

\begin{tabular}{lrrrr}
\hline Perlakuan & Terkecil & Terbesar & \multicolumn{1}{c}{ Kisaran } & Rata-rata $(\mathrm{cm})$ \\
\hline P0 & 30,7 & 39,9 & $30,7-39,9$ & $35,80 \mathrm{a}, \mathrm{b}$ \\
P1 & 35,1 & 45,6 & $35,1-45,6$ & $38,07 \mathrm{~b}$ \\
P2 & 28,5 & 40,5 & $28,5-40,5$ & $37,78 \mathrm{~b}$ \\
P3 & 30,9 & 47,3 & $30,9-47,3$ & $39,22 \mathrm{~b}$ \\
P4 & 32,8 & 40,4 & $32,8-40,4$ & $37,32 \mathrm{~b}$ \\
P5 & 30,3 & 45,2 & $30,3-45,2$ & $37,90 \mathrm{~b}$ \\
P6 & 32,4 & 36,2 & $32,4-36,2$ & $33,88 \mathrm{a}$ \\
\hline
\end{tabular}

Keterangan : Nilai yang diikuti huruf yang berbeda menunjukkan berbeda nyata pada DMRT taraf $5 \%, \mathrm{P} 1$ : Konsentrasi Kolkhisin 0,1\%, P2: Konsentrasi Kolkhisin 0,2 \%, P3: Konsentrasi Kolkhisin 0,3 \%, P4: Konsentrasi Kolkhisin 0,4 \%, P5: Konsentrasi Kolkhisin 0,5 \%, P6: Konsentrasi Kolkhisin 0,6 \%.

\section{KESIMPULAN}

Perlakuan perendaman kolkhisin pada benih oyong dapat menimbulkan perubahan variabel pertumbuhan dan hasil tanaman oyong. Perlakuan kolkhisin dengan konsentrasi $0,3 \%$ menunjukan perubahan positif terhadap bobot basah buah, diameter buah dan panjang buah. Terjadi peningkatan keragaman pada komponen pertumbuhan dan hasil terutama pada perlakuan kolkhisin dengan konsentrasi 0,3\%

\section{DAFTAR PUSTAKA}

Chen WH, CY Tang and YL Kao. 2009. Ploidy doubling by in vitro culture of excised protocorms or protocorm-like bodies in Phalaenopsis species. Plant Cell Tiss Organ Cult. 98:229-238.

Dandge VS, Rothe SP, Pethe A S. 2010. Antimicrobial activity and Pharmacognostic study of Luffa acutangula L.roxb var amara on some deuteromycetes fungi. Int $\mathrm{J}$ of Sci Innovations and Discoveries. 2 (1): 191-196.

Daryono BS, Rahmadani WD. 2009. Karakter Fenotipe Tanaman Krisan (Dendranthema grandiflorum) Kultivar Big Yellow Hasil perlakuan Kolkhisin. J Agrotropika. 14(1): 15-18

Dashora N, Chauhan LS, Kumar N. 2013.Luffa acutangula (Linn.) Roxb. Var. Amara (Roxb.) A Consensus Review. Int J Pharm Bio Sci. 4(2): 835846.

Haryati S, Hastuti RB, Setiani N, Banowo A. 2009. Pengaruh kolkisin terhadap pertumbuhan, ukuran sel metafase dan kandungan protein biji tanaman kacang hijau (Vigna radiata (L) Wilczek). J Pnlt Sains dan Teknologi. 10(2):112-120.

Herawati T, Ridwan S. 2000. Diktat kuliah pemuliaan tanaman lanjutan. Bandung (ID): Fakultas Pertanian Universitas Padjajaran

Kerdsuwan N, S Te-chato. 2012. Effects of colchicine on survival rate, morphological, physiological and cytological characters of chang daeng orchid (Rhynchostylis gigantean var. rubrum Sagarik) in vitro. J Agric Tech. 8:1451-1460.

Kulkarni M, Borse T. 2010. Induced polyploidy with gigas expression for root traits in Capsicum annuum (L.). Plant Breed. 129:461-464.
Liu L, Z Li, M Bao. 2007. Colchicine-induced chromosome doubling in Platanus acerifolia and its effect on plant morphology. Euphytica 157:145-154.

Madon M, Clyde MM, Hashim H,Yusuf YM, Mat H, Saratha S. 2005. Polyploidy induction of oil palm through colchicine and oryzalin treatments. J Oil Palm Res. 17 : 110-123.

Mensah JK, BO Obadoni, PA Akomeah, B Ikhajiagbe, $J$ Ajibolu. 2007. The effects of sodium azide and colchicine treatments on morphological and yield traits of sesame seed (Sesamum indicum L.). African J Biotech. 6:534-538.

Permadi AH, R Cahyani dan S Syarif. 1991. Cara Pembelahan Umbi, Lama Perendaman Dan Konsentrasi Colchicine Pada Poliploidisasi Bawang Merah Sumenep. Zuriat 2(1):17-26.

Rodiansah A. 2007 Induksi Mutasi Kromosom dengan Kolkhisin pada Tanaman Stevia (Stevia rebaudiana Bertoni) Klon Zweeteners secara In Vitro. J Pnltn Sain Tek. 6 (2) 76-82

Sarathum S, M Hegele, S Tantiviwat, and M Nanakorn. 2010. Effect of concentration and duration of colchicine treatment on polyploidy induction in Dendrobium scabrilingue L. Eur $\mathrm{J}$ of Hort Sci. 75:123-127.

Sofia D. 2007. Respon Pertumbuhan dan Produksi Mentimun (Cucumis Sativus L.) dengan Mutagen Kolkhisin. Karya Tulis. Fakultas Pertanian Universitas Sumatera Utara.

Sulistianingsih R, Suyanto ZA, Noer AE. Peningkatan Kualitas anggrek Dendrobium Hibrida dengan Pemberian Kolkisin. IImu Pertanian 11 (1): 13-21.

Suryo 2007. Sitogenetika. Yogyakarta (ID): Gadjah Mada Univesity Press.

Susianti A, Aristya GR, Sutiknorina, Kasiamdari S. 2015. Karakterisasi Morfologi dan Anatomi Stroberi (Fragaria $\mathrm{x}$ ananassa D.cv.Festival) Hasil Induksi Kolkisin. Biogenesis. 3(2) : 66-75.

Tambong JT, VT Sapra dan S Gartun. 1998. In Vitro Introduction of Tetraploid in Colchisine-Treated Watermelon Plantles. Euphytica. 104: 191-197. ISSN: 0014-2336

Yulianti F, A Purwito, A Husni, D Dinarty. 2014. Induksi tetraploid tunas pucuk jeruk Siam Simadu (Citrus nobilis Lour) menggunakan kolkisin secara in vitro. J Agron Indonesia. 42:144-150. 